\title{
Design, Testing and Implementation of a Large-Scale Urban Dog Waste Composting Program
}

\author{
Leah Nemiroff ${ }^{1^{*}}$ and Judith Patterson ${ }^{2}$ \\ 1. Dept. of Biology and Science College, Concordia University, Montreal, Québec, Canada \\ *Now at Dept. of Biology, Dalhousie University, Halifax, Nova Scotia, Canada \\ 2. Environmental Science Programme, Dept. of Geography, Planning and Environment, \\ Concordia University, Montreal, Québec, Canada
}

\begin{abstract}
In Montreal, Québec, many dogs are exercised in fenced-in runs in parks. Consequently, these dog parks are a high-density source of large amounts of dog waste, which is typically collected by the owner in a plastic bag and deposited in the municipal garbage. In 2004, an experimental large-scale dog waste composting programme was initiated at the Notre-Dame-de-Grâce (NDG) dog run in Montreal, Québec. Dog waste was collected with plastic shovels, deposited into compost bins, and layered with sawdust. In two months, a total of $213 \mathrm{~kg}(470 \mathrm{lbs})$ of dog waste was collected and composted, along with $33 \mathrm{~kg}$ (72 lbs) of donated sawdust, in two research compost bins. After a year of incubation, the two bins produced $179 \mathrm{~kg}$ ( $394 \mathrm{lbs})$ of compost. Temperatures in the research bins peaked between $40^{\circ} \mathrm{C}$ and $55^{\circ} \mathrm{C}$ but were not maintained long enough for conclusive elimination of pathogens. Participation by dog run users during the trial project was enthusiastic, and full-scale dog waste composting has now been implemented at the dog run, with nine bins being filled over a 12 month period. On an annual basis, this composting programme diverts almost a ton of dog waste (approximately $959 \mathrm{~kg}(2,115 \mathrm{lbs})$, over $130 \mathrm{~kg}$ ( $300 \mathrm{lbs})$ of sawdust, and at least 7000 plastic bags from Montreal's landfill site, and produces about $770 \mathrm{~kg}(1,700 \mathrm{lbs})$ of compost annually.
\end{abstract}

\section{Introduction}

Effective waste management is an ever-growing issue in urban environments. Recycling is a sustainable strategy for disposing of waste, and composting can be an important part of a recycling programme. For example, 110 municipalities in Sweden have introduced and strictly enforced a biweekly compost collection for household organic waste. This, combined with material recycling and other forms of waste treatment, has reduced the amount of waste going to landfills in Sweden by $65 \%$ from 1994 to 2005 (RVF 2006). Impressively, only $4.8 \%$ of their annual quantity of treated household waste actually made it to a landfill in 2005, and it is now illegal to landfill organic waste (ibid).

Composting is defined here as a controlled aerobic process by which heterogeneous organic waste is converted into a stabilized, hygienic product, containing high levels of humic substances (Chen et al. 1996). Contrary to anaerobic waste disposal systems, properly aerated and controlled composts are a negligible source of $\mathrm{CH}$ and are not a net source of $\mathrm{CO}_{2}$ (Peigné \& Girardin 2004). Composting also decreases the amount of waste going to landfill sites and the product can be used as a beneficial soil amendment product for infertile, unstructured soil and nursery crops (Guisquiani et al.
1995; Fitzpatrick 2001; Wilson \& Mecca 2004).

In the United States alone, it is estimated that dogs and cats produce approximately 10 million tons of waste annually (Brinton and Storms 2004), and the disposal of dog waste can pose a significant problem in areas of high-density dog populations. In 1991, the Fairbanks, Alaska, Soil and Water Conservation District began research on composting dog waste because of the huge amounts of manure being produced by the 20,000 dogs living in the Fairbanks North Star Borough (Freeborne 1994). Pollution from this manure posed threats to water quality, wildlife and public health (Rippy et al. 1997). A trial dog waste composting programme was initiated with volunteer mushers and kennel owners and has grown into a successful programme.

Dog waste is also a problem in large Canadian municipalities. In Quebec, 23\% of residents own at least one dog (Leger Marketing 2002), resulting in an estimated 1,742,728 dogs in Québec and, conservatively, 432,000 on the Island of Montreal alone (Institut de la statistique Québec 2005a,b). On average, a dog produces $0.34 \mathrm{~kg}(0.75 \mathrm{lbs})$ of feces per day (Taylor 2004). Consequently, there are approximately $146,860 \mathrm{~kg}$ $(323,770 \mathrm{lbs})$ of dog waste to be disposed of every day in Montreal. As most dog owners in cities pick up their dog's waste in nonbiodegradable plastic bags, this is 
an additional burden on the city's landfills.

In urban Montreal, a large number of domestic dogs exercise and socialize in fenced-in dog runs in city parks, creating areas with high-density dog activity and, consequently, a large volume of dog waste. A city dog run is therefore an ideal area for testing and implementing a large-scale urban dog manure composting program. The Notre-Dame-de-Grâce (NDG) Dog Run, which opened in 1997, was chosen as the test site for this research for a number of reasons. It is a large dog run in a busy urban area, with an estimated 50-75 dogs frequenting the park every day. It is a reputable and trusted dog run due to the presence of the NDG Dog Run Committee, founded in 1999. As well, it was believed that a trial project would be supported because the users of the dog run have a vested interest in their green space, as evidenced by enthusiastic participation in the semi-annual cleanup events. Finally, it is a large dog park (20,000 square feet), which allowed for the placement of multiple compost bins without any adverse effects on the usage pattern in the run.

The main objective of this research was to develop and determine the feasibility and efficiency of an on-site dog waste composting programme in an urban park, using a passively aerated composting system with dog waste and wood chips as organic matter. If this could be established, both in terms of actual composting and public participation, the second objective was to implement the composting system on a permanent basis. The programme has been a success, and the results are presented below.

\section{Animal Waste Composting}

Composting has been successfully completed using garden waste, solid refuse, and the agricultural waste of pigs, cattle, rabbits, poultry, horses, ducks, sheep and goats (Soliva \& Giro 1992; Rynk 1992; Liao et al. 1993; Lafond et al. 2002). It has even been successfully used to decompose slaughterhouse waste and dead chickens, as well as salmon-farm mortalities (Sims et al. 1992; Liao et al. 1994).

Composting requires suitable temperatures, nutrient availability, oxygen input, moisture content and a 25:1 carbon to nitrogen ratio in order to reach and maintain maximal microbial activity, thereby resulting in increased efficiency and speed of decomposition (Beffa et al. 1996; Stentiford 1996; Rynk 1992). The microorganisms involved oxidize carbon as an energy source for growth and ingest nitrogen for protein synthesis (Taylor 2004). Consequently, the right carbon to nitrogen ratio in composting systems is required for efficient decomposition. On average, wet dog manure contains $0.7 \%$ nitrogen $(\mathrm{N})$,
$0.25 \%$ phosphate $\left(\mathrm{P}_{2} \mathrm{O}_{5}\right)$ and $0.02 \%$ potash $\left(\mathrm{K}_{2} \mathrm{O}\right)$. Compared to wet cattle manure, dog waste contains $40 \%$ more nitrogen, the same amount of phosphate, and $1 / 20$ the amount of potash (Hall \& Schulte 1979). Due to the high nitrogen content of dog manure, a source high in carbon, such as wood chips, shavings or sawdust (C:N ratio of 560-641:1) is needed for efficient decomposition (Rynk 1992). Heat evolution occurs in proportion to metabolic activity and is an efficient method of observing the rate of composting microbial activity (Miller 1996).

\section{Methodology}

\section{Set-up and Education}

The project began in June 2004, with a 10 week trial period. For the purposes of the research it was necessary to collect and weigh the dog manure before putting it into the compost bin. Therefore, four plastic kitchen garbage pails, each with a 0.4 cubic meter (1.3 $\mathrm{ft}^{3}$ ) capacity, were placed, chained and locked throughout the dog run in high traffic areas to act as collection bins. Each collection bin had a secure lid and was lined with a large garbage bag. Collection equipment, consisting of garden trowels and plastic dust pans, was hung nearby. Bilingual (French/English) flyers were made and distributed by the NDG Dog Run Committee during an intensive two week education period, and bilingual signs of explanation were laminated and posted around the dog run in high traffic areas, as well as beside every collection bin. Participants were instructed to pick up dog waste using the collection equipment provided and to deposit it only in the collection bins.

Two round commercial compost bins made of recycled plastic were set up in the dog run in a bright, sunny area a significant distance away from the park benches. Each compost bin has a total capacity of $4 \mathrm{cu}-$ bic meters $\left(13 \mathrm{ft}^{3}\right)$, with a lightweight, locking lid, and holes along all sides for aeration (Table 1). Plastic was

TABLE 1.

Compost bin specifications for dog waste composting at a dog park in Notre-Dame-de-Grâces, Québec

Specifications

\begin{tabular}{ll}
\hline & Specifications \\
\hline Shape & Round \\
Body dimensions & $81 \mathrm{~cm} \times 81 \mathrm{~cm} \times 76 \mathrm{~cm}\left(32^{\prime \prime} \times 32^{\prime \prime} \times 30^{\prime \prime}\right)$ \\
Top opening dimensions & $67 \mathrm{~cm} \times 71 \mathrm{~cm}\left(26.5^{\prime \prime} \times 28^{\prime \prime}\right)$ \\
Total capacity & 4 cubic meters $(13 \mathrm{cubic}$ feet $)$ \\
Composition & $\begin{array}{l}\text { Recycled plastic }(60 \% \text { post-consumer, } \\
\left.40^{\circ} \% \text { post-industrial }\right)\end{array}$ \\
Features & $\begin{array}{l}\text { Locking lid, two } 33 \mathrm{~cm} \times 33 \mathrm{~cm}\left(13^{\prime \prime} \times 13^{\prime \prime}\right) \text { sliding } \\
\text { doors on either side of the base, aeration vents } \\
\text { Brand }\end{array}$ \\
& Smith \& Hawken: The Home Composter
\end{tabular}


taped across the bottom of each compost bin to retain all material, and a $5 \mathrm{~cm}\left(2^{\prime \prime}\right)$ layer of weighed household waste compost and commercial potting soil (mixed at a ratio of $3: 1$ ) was added to the bottom of each bin to separate the fresh feces and wood chips from the plastic and to help activate decomposition. Both bins were chained and locked to the surrounding fence to ensure that they would not be moved. Bilingual "Controlled Research, Do Not Touch" signs were put up on the compost bins to prevent people from adding un-weighed material directly to the research compost bins. Dry wood chips and shavings were donated by a local construction company (D \& G) as the carbon source for composting. The wood material had a mixed provenance, with a range of composition and moisture content. The particle size ranged from 1-2 $\mathrm{cm}^{2}$ flat shavings to dust.

\section{Collection and Maintenance}

The contents of the plastic bag-lined collection bins were a mix of dog feces and gravel, unavoidably picked up during collection of the manure. The material in the collection bins was weighed with a $0.2 \mathrm{~kg} / \mathrm{lb}$ graduation electronic scale (EK5) every 48 hours, and then emptied into the first of the two research compost bins. New plastic bags were then placed in the collection bins to avoid odour build-up. Wood shavings were added to the compost bin at a 10:1 feces to wood mass ratio, calculated according to the procedure outlined in Rynk (1992) and resulting in an estimated C:N ratio of 22.3. The materials were mixed using a metal shovel. Water was added to the compost bin to keep moisture levels at approximately $60-70 \%$, which was verified using a scaled moisture meter ( 0 /dry- 10 /wet, MoistureMeter(C). Rubber gloves were used during every step to prevent parasite transmission.

The first research bin was filled and closed in late July 2004 and allowed to incubate. The second compost bin was filled and closed by early September 2004. The peripheral (approximately $10 \mathrm{~cm}\left(4^{\prime \prime}\right)$ from the bin wall) and central temperatures of each closed compost bin were taken every 48 hours with a lab thermometer. The compost was turned in the compost bins with a metal spade when the temperatures were observed to be decreasing.

\section{Final Measurements}

The research bins were opened and emptied in August 2005. Moisture readings were taken every $10 \mathrm{~cm}$ on a wet basis using the scaled moisture meter $(0 /$ dry- 10 /wet). The mass of the final products (a mix of compost and gravel) was measured using the elec- tronic scale. The gravel was then sifted out of the compost using a $1 / 4$ inch wire screen, and pressurewashed, dried, and weighed. The mass of feces collected and compost produced was determined by subtracting the weight of the gravel from the input and output measurements. A paired t-test was performed on the central and peripheral temperature readings to determine if temperatures between the two compost bins were significantly different from each other. Standard error of input and output weights due to scale inconsistencies was calculated based on 20 repeated measurements of a bucket of soil before experimentation began. All statistical analyses were performed using SYSTAT software, version 11.

Other sources of error were restricted to minor loss of material from shovels used for turning the compost, the sides of the compost bins when dismantled, gloves and other tools used for transferring the compost from the bin to the garbage bags, minor loss of compost due to accidental spillage during weighing of the unsifted compost, and minor loss of gravel due to accidental spillage while cleaning, drying and weighing the gravel.

\section{Implementation of a Permanent System}

Due to the success of the trial research phase, the NDG Dog Run Committee permanently implemented the dog waste composting programme at the NDG dog run. The four collection bins were removed and seven new compost bins were added. A new education programme was launched by the committee in September 2004 , instructing dog owners to now directly deposit dog waste into the compost bins. Currently, there are three compost bins open and being filled, and six closed and reserved for incubating compost.

In the original research bins, the bottom was sealed and starter compost and soil was included. Water was added as needed during the composting process. However, when working with compost bins that are open at the bottom, it is simply necessary to layer the ground with sawdust when starting a new bin. Manure is collected year round and layered daily with sawdust by volunteers. Frozen and layered manure and sawdust needs to be vigorously turned when it thaws in the spring. Also, snow collected along with the feces during the winter melts in the spring and supplies adequate moisture to the compost.

\section{Results}

The two research compost bins in this study showed major decreases in mass, produced no offensive odours, and underwent extensive changes in col- 
or and texture of the materials. The final, mature compost was homogenous in both texture and color after sifting through a $1 / 4$ inch mesh screen. Both bins underwent thermophilic stages, with central temperatures reaching as high as $42^{\circ} \mathrm{C}$ in compost bin 1 , and $55^{\circ} \mathrm{C}$ in compost bin 2 (Figure 1 ). Compost bin 1 maintained a temperature of $39^{\circ} \mathrm{C}$ and higher for three consecutive days, while compost bin 2 was more successful at reaching high temperatures and maintained a central temperature of $50^{\circ} \mathrm{C}$ and higher for three consecutive days. However, a paired t-test indicated that the central temperatures of both bins were not significantly different from each other $(t=1.468, \mathrm{df}=29, p=$ $0.153)$. Peripheral temperatures were different between the two compost bins $(t=3.348, \mathrm{df}=29, p=$ 0.002 ), possibly due to differences in turning effort of the compost during incubation.

The mass of manure collected and mature compost produced was calculated by subtracting the weight of the gravel from the input and output measurements (Table 2). Standard error due to scale inconsistencies (based on 20 repeated measurements) was found to be 0.026 . Averaged between the two trial compost bins, $106.6 \mathrm{~kg}(235.0 \mathrm{lbs})$ of feces and $16.2 \mathrm{~kg}$ ( $35.8 \mathrm{lbs})$ of saw-

(a)

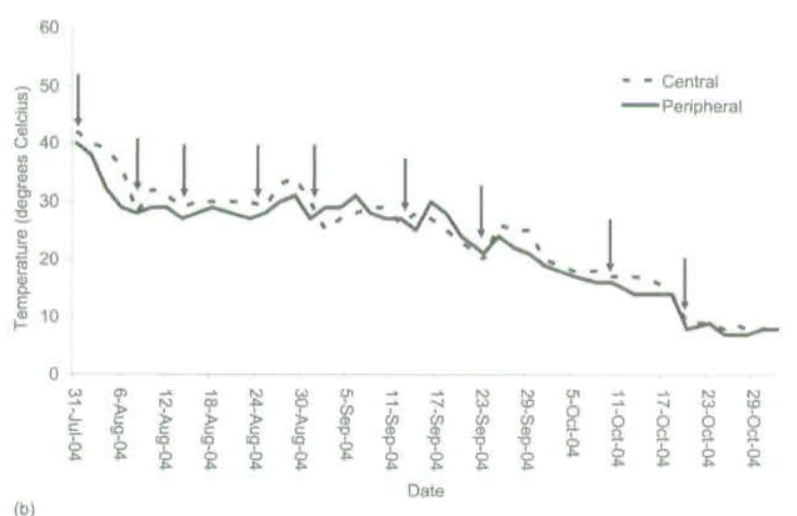

(b)

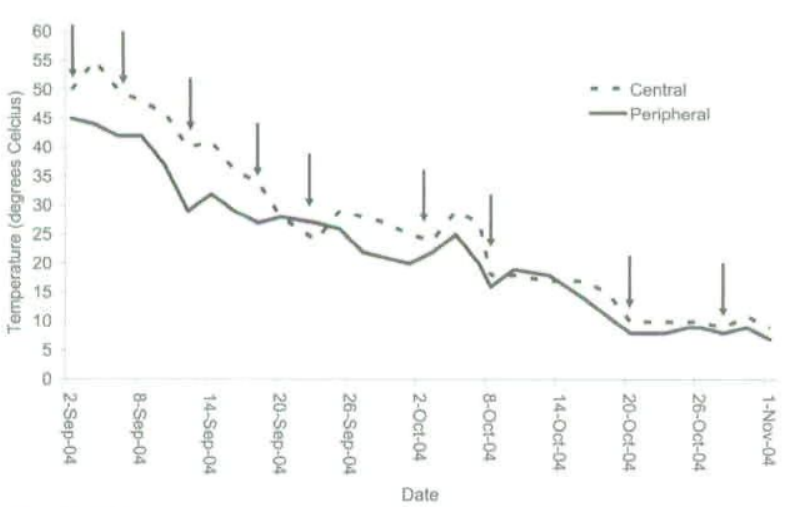

FIGURE 1: The central and peripheral temperature readings for two dog waste compost bins at a dog park in Montreal, Québec. (a) Compost bin 1, (b) Compost bin 2. Turning events are indicated by arrows.
TABLE 2:

Mass (in kilograms) of inputs and outputs for two trial dog waste compost bins

\begin{tabular}{|c|c|c|}
\hline Inputs \& Outputs & Bin \# $1(\mathrm{~kg})( \pm 1 \mathrm{SE})$ & Bin \# $2(\mathrm{~kg})( \pm 1 \mathrm{SE})$ \\
\hline Feces + gravel & $165.8(4.3)$ & $167.4(4.4)$ \\
\hline Clean gravel & $58.5(1.5)$ & $61.5(1.6)$ \\
\hline Mass of feces ${ }^{*}$ & $107.3(2.8)$ & $105.9(2.8)$ \\
\hline Sawdust & $14.6(0.4)$ & $17.9(0.5)$ \\
\hline Starter compost, soil, water & $41.7(1.1)$ & $40.3(1.0)$ \\
\hline Total starting mass & $163.6(4.3)$ & $164.1(4.3)$ \\
\hline Compost + gravel & $150.1(3.9)$ & $148.9(3.9)$ \\
\hline Clean gravel & $58.5(1.5)$ & $61.5(1.6)$ \\
\hline Total compost mass** & $91.6(2.4)$ & $87.4(2.3)$ \\
\hline
\end{tabular}

${ }^{*}$ mass of feces $=($ feces + gravel $)$ - clean gravel.

** mass of compost $=($ compost + gravel $)$ - clean gravel.

dust produced $89.6 \mathrm{~kg}$ (197.2 lbs) of compost after one incubation cycle. Moisture readings of the final compost ranged from $55 \%$ in the top layer to $85 \%$ at the bottom of the compost pile.

In September 2005, one of the new, nonresearch compost bins was emptied, and the compost was screened and weighed, although the gravel was not washed. The weight of the mature compost from this bin was $79.0 \mathrm{~kg}$ ( $174.0 \mathrm{lbs})$, a number consistent with the amount produced from the two research bins, considering the loss of compost that adhered to the gravel from this bin. When these results are prorated over nine bins filled during 12 months, an estimated $960 \mathrm{~kg}$ ( $2115 \mathrm{lbs})$ of feces are collected, $147 \mathrm{~kg}$ ( $325 \mathrm{lbs}$ ) of sawdust are used, and $805 \mathrm{~kg}$ (1775 lbs) of compost are produced annually. Additionally, an estimated 7000 plastic bags containing dog feces are diverted from the landfill site annually.

\section{Discussion}

The design and implementation of a dog waste composting program at an urban dog park was successful. Dog owners participated in the research eagerly. Despite the concerns of many participants, in the summer months there was no discernable bad odour once the dog waste was covered with sawdust in the compost bins, and no odour in the spring when the bins thawed. Over a two month research trial period, $213 \mathrm{~kg}$ ( $470.0 \mathrm{lbs})$ of dog feces were collected and $179 \mathrm{~kg}$ ( $394 \mathrm{lbs}$ ) of compost were produced. Additionally, $33 \mathrm{~kg}$ (72 lbs) of sawdust and an estimated 1250 plastic bags were diverted from Montreal's landfill site.

The optimal moisture content for organic waste at the start of composting is between $40-65 \%$, with more successful results at the higher extreme (Agnew \& Leonard 2003, Stentiford 1996). At 70\%, the average 
moisture reading from this compost, while at the higher extreme, was within the bounds of efficiency.

Dog waste may contain potentially harmful pathogens that can be transmitted to people (USDA 2005). Verocytoxigenic Escherichia coli (E. coli), roundworm eggs, tapeworms, and hookworms are some of the pathogens and parasites easily transmitted to humans from contaminated dog feces (Duffy 2003; Rippy et al. 1997). In the Alaska study, sample compost bins were tested for parasites, and the results indicated that parasites were not found in the finished compost from dog waste known to be contaminated with parasites (Rippy et al. 1997). To ensure complete pathogen elimination, the Ontario Ministry of the Environment requires manure to be composted at $55^{\circ} \mathrm{C}$ for a minimum of five days to meet the standard for unrestricted use compost (A. Wheatley, p. comm. 2005; CCME 2006). In properly controlled large batch compost systems, temperatures can reach between $55^{\circ} \mathrm{C}$ to $65^{\circ} \mathrm{C}$ for three consecutive days or longer, the necessary heat and duration to inactivate pathogens (Duffy 2003; Stentiford 1996; USDA 2005). Unfortunately, in this study, while the temperatures of the trial compost bins reached between $40-55^{\circ} \mathrm{C}$ and were more than high enough for efficient composting of dog waste, the above standards were not met. Consequently, the resulting compost should only be used for flower beds and houseplants, grass on which no children play, or at dog park sites. Care should be taken when handling all dog waste and dog waste compost, and the use of rubber gloves is highly recommended.

Nutrient analysis from previous studies in Alaska indicate that compost from dog manure is high in nitrogen, phosphorus and potassium, and contains high levels of salt, common in compost made from a variety of materials (Rippy et al. 1997). The $\mathrm{pH}$ of the compost was close to neutral (ibid). Due to the high salinity and nutrient content, it is suggested that the compost be mixed at a one to four ratio with commercial potting soil before application (Freeborne 1994).

To date, this programme is the only known largescale urban dog waste composting system. In Toronto, residents can put organic material, including pet waste and used diapers, out for curbside collection (Toronto 2005), but this is on an individual residential basis and does not apply to off-leash dog areas where large numbers of dogs congregate. In Vancouver, a newly amended bylaw required dog owners to take home their dog's waste from public parks and dispose of it themselves. Many people refuse to go to these lengths and, consequently, the amount of dog waste being left on the ground has grown drastically (LEES 2004). In 2004, The National Capital Coalition for People and Dogs proposed to solve the problem by setting up an on-site composting system at Everett Crowley Park (Taylor 2004). As of this writing, the research for this project has not yet begun (C. O'Connell, p. comm. 2006).

\section{Conclusions}

Dog waste composting appears to be a feasible and highly functional method of managing large amounts of dog waste in an environmentally-friendly way. Dog waste composting reduces the amount of waste being sent to landfills (Sequi 1996), reduces the amount of methane being released into the atmosphere (Peigné \& Girardin 2004), and can provide poor soil quality areas with an efficient soil amendment product (Albaladejo et al. 2000). It is estimated that from just this one dog run alone, over a ton of dog manure, over $136 \mathrm{~kg}$ (300 lbs) of sawdust, and approximately 7000 plastic bags are diverted annually from the Montreal landfill site.

The composting program designed and tested during this study has now been fully implemented at the NDG dog park, and a total of nine compost bins are currently being used and maintained by the dog run committee. The resulting compost is sifted and distributed to members of the dog run, and used in flowerpots in the dog run itself. This sustainable composting program allows individuals to benefit directly from their environmentally positive actions, and provides the park with an environmentally-friendly method for effective waste management. This pilot project has demonstrated that large-scale dog waste composting programs can be successfully implemented in urban settings and provide a means of partially reducing solid waste going to municipal landfill sites.

\section{Acknowledgements}

The authors thank the entire dog run committee (S. Belanger, J. Fares, E. Salamon, T. Nudel, \& C. Dirlikov) for their help and support, and the users of the dog run, both human and canine, for their participation and enthusiasm. We also thank S. Vais, B. Goyer, and the many conscripted turning and screening volunteers for repeatedly going beyond the call of duty. Special thanks to S. Belanger for her translation services, and to D \& G Construction for donating materials. D. Greene, M. McCavour, and an anonymous reviewer provided helpful comments on an earlier version of this manuscript. This work was supported equally by J. Patterson's Concordia University G.P.P.I. grant and by funding from the NDG Dog Run Association. 


\section{References}

Agnew, J.M., Leonard, J.J. (2003). The Physical Properties of Compost. Compost Science \& Utilization, Vol. 11 (3): 238-264.

Albaladejo, J., Castillo, V., Díaz, E. (2000). Soil loss and runoff on semiarid land as amended with urban solid refuse. Land Degradation \& Development, Vol. 11: 363-373.

Beffa, T., Blanc, M., Marilley, L., Fischer, J.L., Lyon, P-F., Aragno, M. (1996).Taxonomic and Metabolic Microbial Diversity During Composting. In: The Science of Composting, edited by de Bertoldi, M.D., Sequi, P., Lemmes, B., Papi, T. Glasgow, United-Kingdom: Blackie Academic and Professional, pgs 149-160.

Brinton, W.F., Storms, P.H. (2004). Microbiological test qualities of composted manures and yardwastes. World Congress Organic Food, Michigan State University, March 29-31.

Chen, Y., Chefetz, B., Hadar, Y., (1996). Formation and properties of humic substance originating from composts. In: The Science of Composting, edited by de Bertoldi, M.D., Sequi, P., Lemmes, B., Papi, T. Glasgow, United-Kingdom: Blackie Academic and Professional, pgs 382-393.

CCME (2006). Canadian Environmental Quality Guidelines, Canadian Council of Ministers of the Environment report, 1300pgs.

Duffy, G. (2003). Verocytoxigenic Escherichia coli in animal feces, manures and slurries. Journal of Applied Microbiology, Vol. 94: 94S-103S.

Fitzpatrick, G.F. (2001). Compost utilization in ornamental and nursery crop production systems. In: Compost utilization in horticultural cropping systems, edited by Stofella, P.J., Kahn, B.A. Boca Raton, Florida: CRC Press LLC., pgs. 135-150.

Freeborne, J. (1994). Composting dog manure in Fairbanks. BioCycle, Vol. 35 (1): 70-71.

Guisquiani, P.L., Pagliai, M., Gigliotti, G., Businelli, D., Benetti, A. (1995). Urban Waste Compost - Effects on Physical, Chemical and Biochemical Soil Properties. Journal of Environmental Quality, Vol. 24 (1): 175-182.

Hall, R.E., Schulte, E.F. (1979). Using dog and cat manure on home gardens. University of Wisconsin, Madison, College of Agriculture and Life Sciences.

Institut de la statistique Québec (2005a) : Estimation trimestrielle de la population au 1er avril 2005 et part par province. http://www.stat.gouv.qc.ca/donstat/ econm_ finnc/ conjin_econm/TSC/ [cited Aug. 30, 2005].

Institut de la statistique Québec (2005b) : Tableaux statistiques. http://www.stat.gouv.qc.ca/regions/profils/profil06/societe/demographie/demo_gen/pop_a ge06.htm [cited: Aug. 30, 2005].

Lafond, S., Pare, T., Dinel, H., Schnitzer, M., Chambers, J.R., Jaouich, A. (2002). Composting duck excreta enriched wood shavings: $\mathrm{C}$ and $\mathrm{N}$ transformations and bacterial pathogen reductions. Journal of Environmental Science and Health, part B, Vol. 37(2): 173-186.

LEES and Associates (2004). Dealing with dog waste in Vancouver parks: Preliminary research for dog waste composting at Everett Crowley Park. Environmental planning report, pgs 1-15.

Leger Marketing (2002). Canadians and their Pets, Canadian Trends Report. Canadian Press/Leger Marketing, pgs 2-3.
Liao, P.H. Vizcarra, A.T., Lo, K.V., Chen, A., Lo, K. V. (1993). Composting of separated solid swine manure. J-environ-sci-health,-part-A,-environ-sci-eng, Vol. 28 (9) :1889-1901.

Liao, P.H., Vizcarra, A.T., Lo, K.V. (1994). Composting of salmon-farm mortalities. Biores-technol, Vol. 47 (1): 67-71.

Miller, F.C. (1996). Heat Evolution during Composting of Sewage Sludge. In: The Science of Composting, edited by de Bertoldi, M.D., Sequi, P., Lemmes, B., Papi, T. Glasgow, United-Kingdom: Blackie Academic and Professional, pgs 106-115.

O'Connell, C. (2006). Chairperson, The National Capital Coalition for People and Dogs, City of Vancouver: Personal Communication.

Peigné, J., Girardin, P. (2004). Environmental impacts of farm-scale composting practices. Water, Air, and Soil Pollution, Vol. 153: 45-68.

Rippy, A., Gleason, M., Ash, A., Willingham, S. (1997). Composting Dog Waste in Interior Alaska, Fairbanks Soil and Water District, Study Details, CWA Section 319 Progress Report, Project \#: 8-FY92-AK, 14 pgs.

RVF (2006). Swedish Waste Management. The Swedish Association of Waste Management, Annual publication of the RVF. 26pgs.

Rynk, R. (editor) (1992). On-Farm Composting Handbook. Ithaca, New York: Natural Resource, Agriculture, and Engineering Service (NRAES), pgs 12, 20.

Sequi, P. (1996). The Role of Composting in Sustainable Agriculture. In: The Science of Composting, edited by de Bertoldi, M.D., Sequi, P., Lemmes, B., Papi, T. Glasgow, United-Kingdom: Blackie Academic and Professional, pgs 23-29.

Sims, J.T., Murphy, D.W., Handwerker, T.S. (1992). Composting of poultry wastes: implications for dead poultry disposal and manure management, Journal of Sustainable Agriculture, Vol. 2 (4): 67-82.

Soliva, M., Giro, F. (1992). Composting of three kinds of residues of very different origin, Acta Horticulturae, Vol. 302: 181-192.

Stentiford, E.I. (1996). Composting Control: Principles and Practice. In: The Science of Composting, edited by de Bertoldi, M.D., Sequi, P., Lemmes, B., Papi, T. Glasgow, United-Kingdom: Blackie Academic and Professional, pgs 49-59.

Taylor, L. (2004). Poop, Scoop and Compost: Proposal to Explore the Feasibility of Composting Dog Waste in Public Parks. Vancouver, Canada: National Coalition for People and Dogs, Handout, pgs. 1-7.

Toronto (2005). Green Bin Program. City of Toronto: www.city.toronto.on.ca/greenbin/card.htm, [cited: Aug. 19, 2005]

USDA (2005). United States Department of Agriculture, National Resources Conservation Service. Backyard Conservation Tip Sheet.

Wheatley, A. (2005). Supervisor, Processing Operations, Organics Works and Emergency Services, City of Toronto: Personal Communication.

Wilson, S.B., Mecca, L.K. (2004). Evaluation of Compost as a Viable Medium Amendment for Containerized Perennial Production, Acta Horticulturae, Vol. 659: 697-703. 
Copyright of Compost Science \& Utilization is the property of JG Press, Inc. and its content may not be copied or emailed to multiple sites or posted to a listserv without the copyright holder's express written permission. However, users may print, download, or email articles for individual use. 